\title{
Meningkatkan keterampilan motorik halus melalui kegiatan menggambar dengan teknik finger painting pada anak kelompok B2 di TK Negeri Pembina Bantul
}

\author{
Sri Sukarini \\ TK Negeri Pembina Bantul Yogyakarta \\ Jl. Parangtritis Km 8.5 Tembi Timbulharjo Sewon Bantul Yogyakarta Indonesia \\ E-mail: Srisukarini13@gmail.com
}

\begin{tabular}{|c|c|}
\hline ARTICLE INFO & ABSTRACT \\
\hline $\begin{array}{l}\text { Article history: } \\
\text { Received: } 25-04-2020 \\
\text { Revised: } 05-05-2020 \\
\text { Accepted: } 15-05-2020 \\
\text { Keywords: } \\
\text { kemampuan motorik halus, } \\
\text { menggambar, finger } \\
\text { painting, anak }\end{array}$ & $\begin{array}{l}\text { Penggunaan metode pembelajaran yang kreatif diperlukan untuk menarik minat } \\
\text { anak. Penelitian ini bertujuan untuk meningkatkan kemampuan motorik halus } \\
\text { melalui kegiatan menggambar melalui teknik finger painting pada anak } \\
\text { kelompok B2 di TK Pembina Negeri Bantul. Penelitian ini merupakan penelitian } \\
\text { tindakan kelas yang menggunakan metode Kemmis dan Mc Taggart. Adapun } \\
\text { subjek penelitian adalah } 19 \text { anak yang terdiri dari } 6 \text { anak laki-laki dan } 13 \text { anak } \\
\text { perempuan. Metode pengumpulan data menggunakan observasi, dan instrumen } \\
\text { pengumpulan data berupa lembar observasi. Kriteria keberhasilan dalam } \\
\text { penelitian ini adalah apabila minimal } 80 \% \text { anak sudah mencapai BSH } \\
\text { (Berkembang Sesuai Harapan) ataupun BSB (Berkembang Sangat Baik). } \\
\text { Adapun teknik analisis data menggunakan analisis data kuantitatif dan kualitatif. } \\
\text { Hasil penelitian menunjukkan bahwa kemampuan motorik halus anak dapat } \\
\text { ditingkatkan melalui kegiatan menggambar dengan teknik finger painting. Hal } \\
\text { ini dapat dilihat dari peningkatan jumlah anak yang memperoleh BSH, yaitu dari } \\
21,1 \% \text { menjadi } 42,1 \% \text {, dan BSB dari 15,7\% menjadi 47,4\%. Adapun langkah- } \\
\text { langkah menggambar dengan teknik finger painting yaitu: 1) Mulai menggambar } \\
\text { bagian yang menjadi objek utama; 2) Lukis perlahan membentuk objek yang } \\
\text { diinginkan dengan menggerakkan jari dengan berputar; 3) Gambar objek-objek } \\
\text { lain untuk melengkapi gambar; 4) Berilah guratan atau garisan pada gambar } \\
\text { dengan menggunakan lidi atau pensil; dan 5) Jika sudah selesai kemudian } \\
\text { dijemur atau biarkan terbuka agar gambar mengering. }\end{array}$ \\
\hline
\end{tabular}

The use of creative learning methods is needed to attract children's interests. This study aims to improve fine motor skills through drawing activities through finger painting techniques in children of group B2 in TK Pembina Negeri Bantul. This research is a classroom action research using Kemmis and Mc Taggart methods. The research subjects were 19 children consisting of 6 boys and 13 girls. Data collection methods using observations, and data collection instruments in the form of observation sheets. The criterion for success in this study is if a minimum of $80 \%$ of children have reached BSH (Developed as Expected) or BSB (Developed Very Good). The data analysis technique uses quantitative and qualitative data analysis. The results showed that children's fine motor skills can be improved through folding activities. This can be seen from the increase in the number of children receiving BSH, from $21.1 \%$ to $42.1 \%$ and BSB from $15.7 \%$ to $47.4 \%$. The steps of drawing with finger painting techniques are: 1) Start drawing the part that is the main object; 2) Painting slowly to form the desired object by moving the finger by rotating; 3) Draw the other objects to complete the picture; 4) Give a stroke or a line to the drawing using a stick or pencil; and 5) When it is finished then dry or leave it open so the image dries. 


\section{PENDAHULUAN}

Pendidikan Anak Usia Dini (PAUD) merupakan suatu upaya pembinaan yang ditujukan kepada anak sejak lahir sampai dengan usia enam tahun. Pembinaan dilakukan melalui pemberian rangsangan pendidikan untuk membantu pertumbuhan dan perkembangan jasmani dan rohani. Tujuan pembinaan ini agar anak memiliki kesiapan dalam memasuki pendidikan lebih lanjut. Usia dini sering disebut dengan istilah golden age atau usia emas. Pada rentang usia ini, anak mengalami pertumbuhan dan perkembangan yang sangat pesat dalam berbagai aspek. Usia prasekolah merupakan waktu yang paling optimal untuk perkembangan motorik anak.

Usia 4-6 tahun merupakan masa peka yang penting bagi anak untuk memperoleh pendidikan. Pengalaman yang diperoleh anak dari lingkungan termasuk stimulasi yang diberikan oleh orang dewasa, akan mempengaruhi kehidupan anak di masa yang akan datang. Berbagai upaya diperlukan agar mampu memfasilitasi anak dalam masa tumbuh kembangnya berupa kegiatan pendidikan dan pembelajaran sesuai dengan usia, kebutuhan, dan minat anak. Beberapa faktor pendukung suksesnya pembelajaran, diantaranya tersedianya guru-guru yang kreatif, pemanfaatan strategi pembelajaran yang inovatif, dan penggunaan media sesuai dengan karakteristik peserta didik. Faktor-faktor tersebut diyakini mampu menciptakan suasana pembelajaran yang kondusif.

Hasil observasi awal pembelajaran keterampilan motorik halus menunjukkan bahwa dari 19 anak hanya 4 anak yang telah berada dalam Tingkat Pencapaian Perkembangan (TPP) yaitu masuk kriteria Berkembang Sesuai Harapan (BSH), sedangkan sejumlah 15 anak masih dalam bimbingan guru. Hal ini ditunjukkan oleh sikap anak yang kurang antusias dalam mengikuti pembelajaran dan lambatnya pengumpulan penyelesaian tugas dalam pembelajaran. Selain itu, 12 anak belum mampu menggambar sesuai imajinasinya, sehingga cenderung meniru contoh guru, serta 12 anak belum mampu menjahit dengan terampil dan sesuai pola.

Pembelajaran dalam era sekarang diarahkan pada pembelajaran yang berpusat pada anak. Anak diposisikan sebagai subjek yang diakui telah memiliki potensi untuk dikembangkan. Untuk mengatasi masih rendahnya kemampuan motorik halus anak, maka peneliti menggunakan kegiatan menggambar dengan teknik finger painting. Finger painting adalah melukis dengan jari. Kegiatan menggambar dengan teknik finger painting dapat mengaktifkan pengetahuan yang telah dimiliki dan membangun respon yang positif, sehingga anak merasa tertarik dan senang dalam kegiatan pembelajaran. Dalam pengembangan motorik halus, teknik finger painting perlu dilakukan karena sesuai dengan karakteristik perkembangan anak. Dampak positif dari penggunaan teknik finger painting adalah anak menjadi termotivasi, motorik halus berkembang dengan baik, anak mendapat kesempatan untuk berkreasi, anak tidak bosan, kemauan anak untuk belajar meningkat, dan anak menjadi antusias dalam mengikuti pembelajaran. Berdasarkan latar belakang tersebut, maka dilakukan penelitian tindakan kelas dengan judul meningkatkan keterampilan motorik halus melalui kegiatan menggambar dengan teknik finger painting.

\section{METODE}

Penelitian ini termasuk Penelitian Tindakan Kelas (PTK). Menurut Wardhani (2010: p 1-4), penelitian tindakan kelas adalah penelitian yang dilakukan oleh guru di kelasnya sendiri melalui refleksi diri dengan tujuan memperbaiki kinerjanya sehingga hasil belajar siswa meningkat dan dilakukan dengan sistem siklus. Adapun alur penelitian tindakan kelas dapat dilihat seperti Gambar 1. 


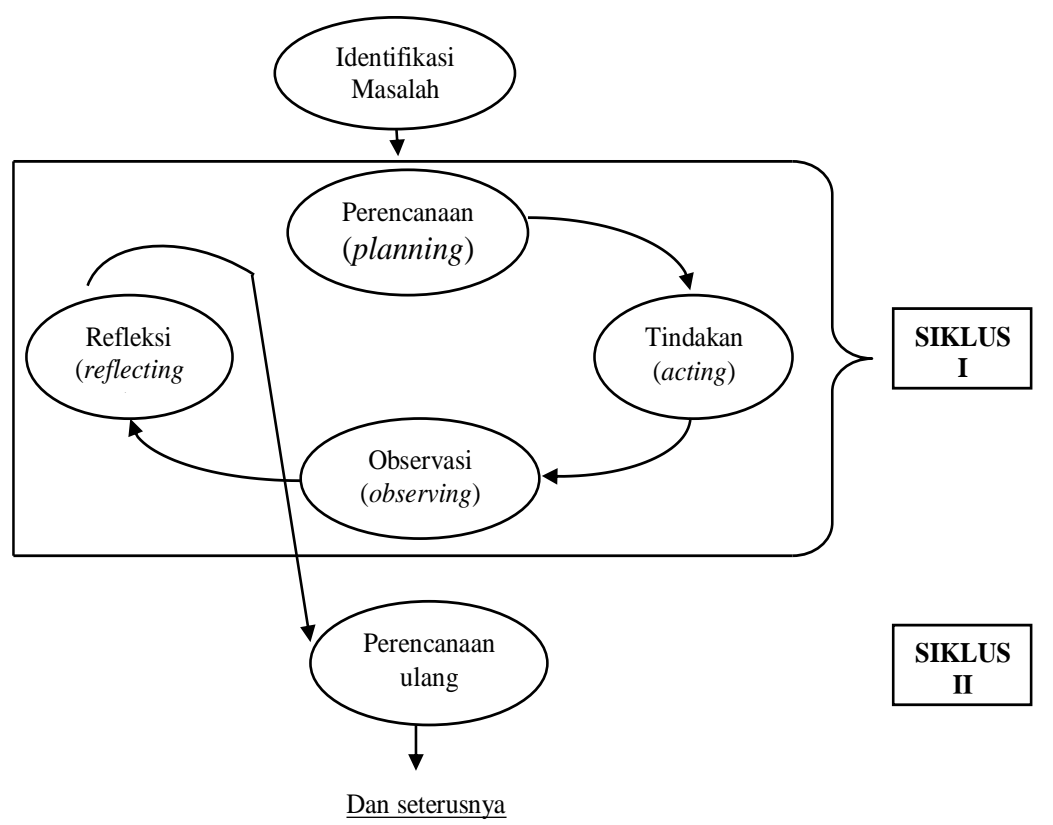

Gambar 1. Alur penelitian tindakan kelas

Metode pengumpulan data dilakukan dengan observasi yang dilengkapi dengan instrumen berupa lembar observasi. Dalam lembar observasi tersebut disediakan empat penilaian yaitu: Belum Berkembang (BB), Mulai Berkembang (MB), Berkembang Sesuai Harapan (BSH), dan Berkembang Sangat Baik (BSB), dengan cara memberi tanda ceklis (v) pada kategori kemandirian dalam menyelesaikan kegiatan finger painting, keterampilan jari tangan, serta penggunaan warna. Selanjutnya, analisis data dilakukan dengan teknik analisis kuantitatif berupa kuantitatif deskriptif berupa hasil pengamatan yang menunjukkan tingkat kemampuan motorik halus anak dari kondisi awal hingga data peningkatan motorik halus anak pada akhir siklus, serta analisis data kualitatif yang mendeskripsikan proses tindakan selama penelitian.

\section{HASIL DAN PEMBAHASAN}

\section{Hasil \\ Pratindakan}

Pelaksanaan Pratindakan dilaksanakan dengan menggunakan teknik pengumpulan data observasi dan lembar hasil karya setiap anak. Keterampilan motorik halus anak kelompok B2 di TK Negeri Pembina Bantul yaitu dari 19 anak hanya 4 anak yang telah berada dalam Tingkat Pencapaian Perkembangan (TPP) yaitu kriteria Berkembang Sesuai Harapan (BSH), sejumlah 15 anak belum maksimal dan saat mengerjakan masih perlu bantuan guru, 12 anak belum mampu menggambar sesuai imajinasinya, sehingga cenderung meniru contoh guru, serta 12 anak belum mampu menjahit dengan terampil dan sesuai pola.

Berdasarkan data observasi dan hasil karya pada anak kelompok B2 di TK Negeri Pembina Bantul, maka peneliti berusaha mencari solusi dan melakukan perbaikan saat kegiatan motorik halus melalui menggambar dengan teknik finger painting. Hal ini dimaksudkan agar keterampilan motorik halus anak meningkat. Peneliti ingin meningkatkan keterampilan motorik halus anak melalui kegiatan menggambar dengan teknik finger painting dengan harapan kemampuan motorik halus anak kelompok B2 di TK Negeri Pembina Bantul dapat meningkat dan mengalami perubahan sesuai dengan tujuan yang diharapkan. 
Siklus I

Perencanaan

Perencanaan tindakan meliputi perencanaan pembelajaran berupa Rencana Pelaksanaan Pembelajaran Harian (RPPH), persiapan bahan dan alat untuk kegiatan dan membuat lembar penilaian observasi, dan hasil karya kegiatan pembelajaran pada anak. Rencana Pelaksanaan Pembelajaran terdiri dari dua pertemuan. Pertemuan pertama membahas tema bencana alam dengan sub tema gunung meletus di laksanakan di area sains yaitu menggambar gunung dengan teknik finger painting. Pada pertemuan kedua masih dilaksanakan di area sains menggambar pohon dengan teknik finger painting.

\section{Pelaksanaan/Tindakan}

Siklus I pertemuan pertama dilaksanakan pada hari Kamis tanggal 21 Februari 2019 dengan kegiatan menggambar gunung dengan teknik finger painting. Selanjutnya pertemuan kedua dilaksanakan pada hari Senin, 25 Februari 2019. Anak-anak diajak tanya jawab tentang bencana alam, macam bencana alam, apa penyebabnya. Selanjutnya masuk kegiatan inti, guru menjelaskan dan memberi contoh cara menggambar dengan teknik finger painting di area sains

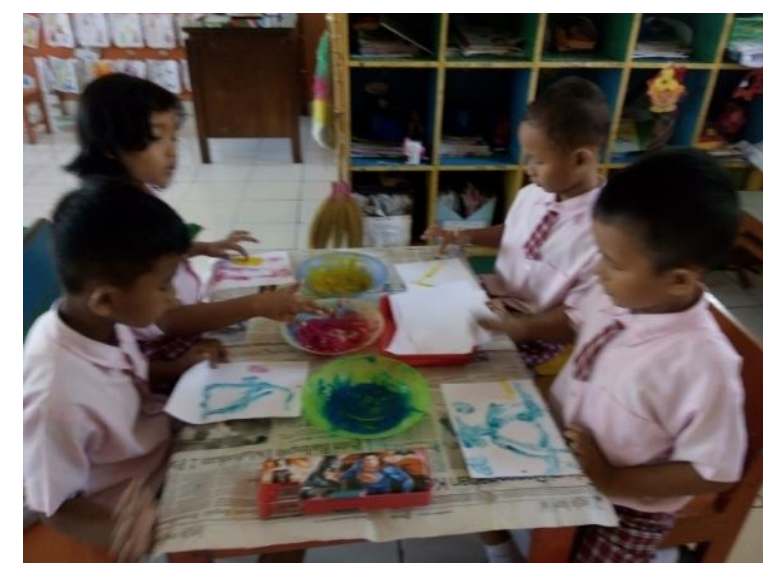

Gambar 2. Anak sedang kegiatan belajar mengajar menggambar gunung dengan teknik finger painting

\section{Pengamatan/Observasi}

Berdasarkan hasil pengamatan dalam pembelajaran diketahui bahwa, keterampilan motorik halus anak melalui menggambar dengan teknik finger painting pada Siklus I berjalan dengan baik. Hal ini tampak dari sebagian anak antusias dalam mengikuti pembelajaran daripada sebelumnya. Dalam proses pembelajaran tampak adanya peningkatan keterampilan motorik halus, yaitu dari 19 anak, sejumlah 3 anak berada pada kriteria BSB, 4 anak berada pada kriteria BSH, dan 12 anak masih berada pada kriteria MB. Meskipun sebagian terlihat antusias dalam mengikuti proses pembelajaran, namun keterampilan motorik halus anak masih belum sesuai harapan. Hal ini dilihat dari hasil pengamatan bahwa masih ada 12 anak yang masih berada pada kriteria Mulai Berkembang (MB). Hal ini karena anak masih belum berani dalam menggunakan 3 warna, kreativitas menggambarnya masih kurang, dan bentuk yang digambar belum terlihat jeals.

Tabel 1. Kemampuan motorik halus pada Siklus I

\begin{tabular}{lcc}
\hline Kriteria & Anak & Persentase \\
\hline MB & 12 & $63,2 \%$ \\
\hline BSH & 4 & $21,1 \%$ \\
\hline BSB & 3 & $15,7 \%$ \\
\hline Jumlah & & $100 \%$ \\
\hline
\end{tabular}


Berdasarkan Tabel 1 dapat dilihat hasil pengamatan keterampilan motorik halus anak melalui menggambar dengan teknik finger painting baru mencapai 7 anak $(36,8 \%)$ yang telah mencapai BSH dan BSB, sehingga masih ada 12 anak $(63,2 \%)$ yang berada pada kriteria MB.

\section{Refleksi}

Pelaksanaan kegiatan pada Siklus I dianggap belum memenuhi target $80 \%$, sehingga perlu dilanjutkan pada Siklus II. Hasil refleksi kegiatan pengembangan keterampilan motorik halus anak pada Siklus I dalam kegiatan menggambar dengan teknik finger painting menunjukan bahwa, hasilnya cenderung meningkat meskipun belum seperti yang diharapkan. Hal ini menunjukkan bahwa kegiatan tersebut dapat melatih kemampuan motorik halus dan kreativitas anak. Namun masih ada sebagian anak yang masih mengerjakan belum maksimal karena 1 mangkuk pewarna digunakan 5 anak, pewarna dalam mangkuk tercampur warna lain sehingga anak sesudahnya tidak lagi warna dasar, jumlah serbet yang digunakan masih kurang, dan anak belum menggunakan 3 warna dengan maksimal.

Tabel 2. Refleksi Siklus I

\begin{tabular}{ll}
\hline Simpulan Siklus 1 & Tindak lanjut Siklus 2 \\
\hline $\begin{array}{l}\text { Pemakaian warna kurang } \\
\text { maksimal }\end{array}$ & $\begin{array}{l}\text { Diberi dorongan agar } \\
\text { menggunakan tiga warna }\end{array}$ \\
\hline $\begin{array}{l}\text { Jumlah mangkuk dan serbet } \\
\text { kurang }\end{array}$ & $\begin{array}{l}\text { Diperbanyak jumlah mangkuk } \\
\text { dan serbet yang digunakan anak }\end{array}$ \\
\hline Kreativitas anak kurang & Diberi contoh gambar oleh guru \\
\hline
\end{tabular}

\section{Siklus II \\ Perencanaan}

Perencanaan tindakan meliputi perencanaan pembelajaran berupa Rencana Pelaksanaan Pembelajaran Harian (RPPH), persiapan bahan dan alat untuk kegiatan dan membuat lembar penilaian observasi kegiatan pembelajaran pada anak. Rencana Pelaksanaan Pembelajaran terdiri dari dua pertemuan. Pertemuan pertama membahas tema tanah airku, dengan sub tema kota di laksanakan di area sains yaitu menggambar kota dengan teknik finger painting. Pada pertemuan kedua masih dilaksanakan di area sains menggambar hotel dengan teknik finger painting. Perencanaan selanjutnya yang dilakukan peneliti pada Siklus II yaitu instrumen untuk pengumpulan data berupa lembar observasi untuk anak dan guru melakukan persiapan mencari gambar perbedaan antara1 warna, 2 warna dan 3 warna, menyiapkan jumlah mangkuk untuk adonan warna, serbet, serta adonan pewarna.

\section{Pelaksanaan/Tindakan}

Siklus II pertemuan pertama dilaksanakan pada hari Jum'at tanggal 8 Maret 2019 dengan kegiatan menggambar kota dengan teknik finger painting. Selanjutnya pertemuan kedua Siklus II dilaksanakan pada hari Sabtu, 9 Maret 2019. Adapun langkah-langkah yang dilakukan guru antara lain: 1) guru memberi contoh cara menggambar dengan teknik finger painting yang benar dengan berbagai warna; 2) guru mengadakan tanya jawab dan mengkomunikasikan perbedaan antara gambar dengan menggunakan 1 warna, 2 warna dan 3 warna; 3) anak-anak mengerjakan tugas di area yang dibuka sesuai dengan pilihan anak. Apabila selesai mengerjakan satu tugas kemudian diberi nilai sedangkan untuk Lembar Kegiatan Anak (LKA) dipajang di papan hasil karya, sehingga anak dapat melanjutkan tugas yang lain sesuai pilihannya; dan 4) guru memberi bimbingan pada anak yang belum mampu, serta mencatat dan mendokumentasikan hasil kegiatan maupun hasil pengamatan atas pencapaian perkembangan anak. 


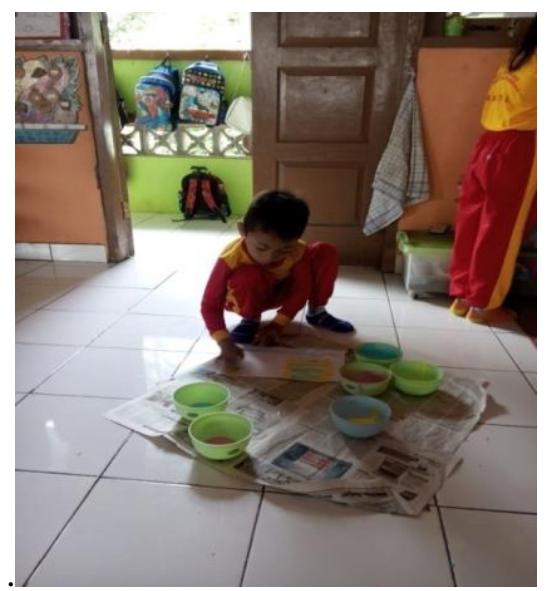

Gambar 3. Anak sedang menggambar kota dengan teknik finger painting

\section{Pengamatan/Observasi}

Hasil pengamatan dalam pembelajaran menunjukkan bahwa keterampilan motorik halus anak melalui menggambar dengan teknik finger painting pada Siklus II berjalan dengan lebih baik. Anak-anak sudah dapat membedakan antara gambar yang menggunakan 1 warna, 2 warna dan 3 warna. Hampir semua anak mengatakan lebih bagus yang menggunakan 3 warna. Dalam proses pembelajaran tampak adanya peningkatan keterampilan motorik halus pada anak. Dari 19 anak, sejumlah 5 anak berada pada kriteria BSB, 8 anak berada pada kriteria BSH, 6 anak berada pada kriteria MB. Sebagian anak mengerjakan dengan semangat, dan tanpa disuruh langsung memilih area sains secara bergantian dan mandiri dalam mengerjakan kegiatan.

Anak-anak semakin terampil dalam menggerakkan jemari tangan saat menggambar dengan teknik finger painting. Selain itu perkembangan lain yang terstimulasi melalui kegiatan menggambar dengan teknik finger painting ini yaitu imajinasi, keberanian menggunakan ketiga warna yang ada, kreativitas mencampur berbagai warna, serta bentuk gambar yang semakin jelas dan proporsional.

Tabel 3. Kemampuan motorik halus pada Siklus II

\begin{tabular}{lcc}
\hline Kriteria & Anak & Persentase \\
\hline MB & 2 & 10,5 \\
\hline BSH & 8 & 42.1 \\
\hline BSB & 9 & 47.4 \\
\hline Jumlah & 19 & $100 \%$ \\
\hline
\end{tabular}

Berdasarkan Tabel 3, maka dapat dilihat hasil pengamatan keterampilan motorik halus anak melalui menggambar dengan teknik finger painting mencapai 9 anak $(47,4 \%)$ berada pada kriteria BSB, 8 anak (42.1\%) berada pada kriteria BSH, dan 2 anak $(63,2 \%)$ berada pada kriteria MB.

\section{Refleksi}

Berdasarkan hasil refleksi kegiatan pengembangan keterampilan motorik halus anak pada Siklus II dalam kegiatan menggambar dengan teknik finger painting dapat disimpulkan bahwa hasilnya cenderung meningkat seperti yang diharapkan, yaitu $89,5 \%$ anak yang berada pada kategori BSH dan BSB. Hal ini menunjukkan bahwa kegiatan menggambar dengan Teknik finger painting dapat meningkatkan keterampilan motorik halus anak. Kemampuan motorik halus anak telah mencapai kriteria keberhasilan minimal $80 \%$ anak berada pada kriteria BSH dan BSB, sehingga penelitian tindakan dihentikan. 


\section{Pembahasan}

Berdasarkan hasil Siklus I dan Siklus II maka diketahui bahwa keterampilan motorik halus anak dapat ditingkatkan melalui kegiatan menggambar dengan teknik finger painting. Peningkatan yang telah dicapai melalui beberapa perbaikan pada pembelajaran di kelas diantaranya:

1. Penggunaan media yang semula pada Siklus I dengan ukuran kertas separuh HVS, kemudian pada Siklus II menggunakan kertas ukuran HVS folio.

2. Mangkok yang digunakan pada Siklus I yaitu 1 mangkok untuk 5 anak, pada Siklus II menjadi 1 mangkok untuk 3 anak.

3. Pemberian reward pada anak yang menyelesaikan tugas dengan kreatif dan mandiri.

4. Pemberian motivasi melalui hasil karya yang telah dibuat anak.

Hasil observasi yang dilakukan guru dan kolaborator yaitu masih ada 10,5\% anak yang berada pada kriteria Mulai Berkembang (MB). Adapun kelemahan yang masih ditemukan yaitu:

1. Anak kurang kreatif dalam menggambar dan tampak masih meniru contoh gambar guru.

2. Meski sudah disediakan serbet, masih ada anak yang tidak mau membersihkan jari tangan ketika hendak ganti warna lainnya.

Kegiatan menggambar dengan teknik finger painting sesuai dengan karakteristik dan perkembangan motorik halus anak. Hal tersebut diperkuat Peraturan Menteri Pendidikan dan Kebudayaan Republik Indonesia Nomor 137 Tahun 2014 bahwa indikator perkembangan motorik halus anak usia 4-5 tahun adalah sebagai berikut: membuat garis vertikal, horizontal, lengkung kiri/kanan, miring kiri/kanan dan lingkaran, menjiplak bentuk, mengkoordinasikan mata dana tangan untuk melakukan gerakan yang rumit, melakukan gerakan manipulatif untuk mengahasilkan suatu bentuk, dengan menggunakan media, mengekspresikan diri dengan berkarya seni menggunakan berbagai media, dan mengontrol gerakan tangan yang menggunakan otot halus (menjumput, mengelus, mencolek, mengepal, memelintir, memilin, meremas).

\section{SIMPULAN}

Berdasarkan hasil penelitian maka dapat disimpulkan bahwa keterampilan motorik halus dapat ditingkatkan melalui kegiatan menggambar dengan teknik finger painting. Hal ini dapat dilihat dari adanya peningkatan jumlah anak yang berada pada kriteria BSH dari 21,1\% menjadi $42,1 \%$ dan kriteria BSB dari $15,7 \%$ menjadi $47,4 \%$. Adapun langkah-langkahnya yaitu: 1) Mulai menggambar bagian yang menjadi objek utama;2) Lukis perlahan membentuk objek yang diinginkan dengan menggerakkan jari dengan berputar; 3) Gambar objek-objek lain untuk melengkapi gambar; 4) Berilah guratan atau garisan pada gambar dengan menggunakan lidi atau pensil; dan 5) Jika sudah selesai kemudian dijemur atau biarkan terbuka agar gambar mengering.

\section{UCAPAN TERIMA KASIH}

Terima kasih peneliti ucapkan kepada pihak sekolah yang sangat membantu proses dari awal hingga penyelesaian penelitian ini, dan tak lupa kepada teman-teman yang saling mendukung dan memberi semangat kepada peneliti. 
Jurnal Pendidikan Anak, Volume 9 (2), Tahun 2020

Sri Sukarini

\section{DAFTAR PUSTAKA}

Aisyah, S. (2013). Perkembangan dan konsep dasar pengembangan anak usia dini. Tangerang: Universitas Terbuka.

Arikunto, A. (2010). Penelitian tindakan kelas. Yogyakarta: Aditya Media.

Hildayani, R. (2011). Psikologi perkembangan anak. Jakarta: Universitas Terbuka.

Susanto, A. (2012). Perkembangan anak usia dini. Jakarta: Kencana Prenada, Media Grup.

Suyanto, S. (2008). Strategi pendidikan anak. Yogyakarta. Hikayat.

Wardani, I. (2012). Penelitian tindakan kelas. Tangerang Selatan: Universitas Terbuka. 